\title{
The Dilemmas of Self-Assertion: \\ Chinese Political Constitutionalism in a Globalized World
}

\author{
Lucas Brang*
}

\section{Forthcoming with Modern China}

\begin{abstract}
Political constitutionalism emerged on the Chinese academic scene in the mid-2000s as a countermovement to the rights-based, court-centered, and textual mainstream in Chinese constitutional scholarship. On the surface, it has launched a biting and sophisticated critique of academic and institutional Westernization and reasserted a sense of Chinese constitutional particularity. However, contrary to its intellectual self-representation as a genuinely Chinese phenomenon, the movement's academic formation, methodological agenda, and theoretical vocabulary are inseparable from global ideological trends and draw heavily on European and American precedents. Consequently, the movement is troubled by a set of performative contradictions. These include the contradiction between its transnational genealogy and nationalist agenda; its pluralist theoretical makeup and anti-pluralist political rhetoric; as well as its putatively value-neutral sociological methodology and the politically selective application of said methodology. These antinomies, I argue, speak to the recurring dilemmas of "national" self-assertion in a globalized world.
\end{abstract}

\section{Keywords}

Chinese constitutional theory, global constitutionalism, globalization of legal thought, theoretical sources of Chinese neoconservatism, dilemmas of national theory-production

\footnotetext{
* PhD candidate, Chair of Chinese Legal Culture, University of Cologne, Germany. Global research fellow, European Union Marie Skłodowska-Curie Actions (2019-2022). Research assistant, Faculty of Law, Chinese University of Hong Kong. Email: lbrang@smail.unikoeln.de. An initial draft of this paper was presented at the 2019 European China Law Studies Association's annual conference in Durham, UK. I would also like to extend my gratitude to Björn Ahl, Albert Chen, Eva Pils, Samuli Seppänen, Daniel Sprick, Wang Jing, as well as the two anonymous referees for their insightful comments on the draft.
} 
Political constitutionalism 政治宪法学 appeared on the Chinese academic scene in the mid2000s as a scholarly movement with political overtones (see Gao, 2014; Albert Chen, 2014; Zheng, 2017; Brang, 2020). Despite lacking a uniform theoretical agenda or manifesto, political constitutionalism has become a widely used rubric under which critical approaches to the methodological mainstream in Chinese constitutional scholarship have gathered. This mainstream-conventionally referred to as “normative constitutionalism” 规范宪法学 or “constitutional hermeneutics” 宪法解释学—exhibits a preference for textual and doctrinal approaches and a propensity to focus on fundamental rights and their judicial enforcement. ${ }^{1}$ Politically, it was emboldened by the domestic debate on the "judicialization of the constitution" which took off in the early 2000s and reached its climax later in the decade, before receding in recent years. Intellectually, it drew on the expansion of liberal constitutionalism as a global normative agenda in the post-Cold War world. In both of these dimensions, domestic and global, a rights-based and judicialized constitutionalism, along with its Chinese proponents, has since come under sustained attack. Despite taking the form of an academic controversy, the political stakes are high; they implicate the nature of legal reasoning and its relation to politics: "Should constitutional scholarship depart from reality and form a closed-off normative system of its own, or should the normativity of the constitution be linked to social and political reality?" (Li Zhongxia, 2011: 161).

Beginning in the mid-2000s, several authors started questioning the textual mainstream either for its theoretical premises or political consequences. Under the rubric of political constitutionalism, they advanced two distinct yet related lines of criticism. On the one hand, they suggested that the mainstream in Chinese legal scholarship suffers from a formalistic and naïve belief in the transplantability of liberal constitutionalism through textual interpretation and judicial empowerment. On the other, and in a more normative vein, a self-consciously nationalistic group of academics also began explicitly attacking the political ideal of liberal constitutionalism as such. Acting upon a neoconservative and statist sensibility, they put forward a more principled critique of mainstream methodology as amounting to institutional Westernization and intellectual self-Orientalization. In its stead, they developed sophisticated apologies - and counter-teleologies — of Chinese party-state constitutionalism.

In so doing, they also adopted a theoretical vocabulary of particularism and localism that is rich in intellectual origins and eclectic in makeup, but converges upon a set of common ideas. These include a preference for anti-formalist and contextual approaches (Seppänen, 2018); a shift of focus from fundamental rights to state sovereignty and national integration (Veg, 2019); as well as an alliance with historicist and essentialist thinking (Xu, 2010). Given 
that its theoretical language celebrates insurmountable cultural particularities and unwavering local resistance to a state of global constitutionalism that is perceived as equally homogenizing and hegemonic, one might prematurely assume that political constitutionalism is a genuinely Chinese reaction to a genuinely global phenomenon. Against the nemesis of a liberal-leaning jurisprudence transferred from abroad, the conventional narrative seems to suggest, political constitutionalism has reasserted a sense of Chinese particularity and developed an indigenous vision of constitutional theory. However, we should not take the movement's selfrepresentation and its polemical juxtaposition of "local" and "global" at face value.

To begin with, we are bound to misconstrue the formation of political constitutionalism as a scholarly movement unless we contextualize its rise within the global intellectual climate of the post-1989 era. This has two consequences. On the one hand, the present account seeks to better appreciate the long-term structural shifts in Chinese academia since the 1990s-including the rise of postmodernism, the demise of Marxism-Leninism, and the introduction of a new sociology-informed sense of institutional pragmatism - and their subsequent impact upon the agenda of political constitutionalism. On the other hand, I identify the mid and late-2000s as a decisive turning point, when a perceived crisis of intellectual and political dimensions prompted a group of academics to activate these recently introduced theoretical sources to launch a biting critique of mainstream legal academia.

After giving a condensed account of the emergence of political constitutionalism, the article turns to some of the argumentative strategies frequently employed by its adherents. It distinguishes two scholarly agendas which underlie the movement and coexist in tension: a "critical-realist" agenda that is primarily concerned with a methodological critique of mainstream textualism, and a neoconservative agenda that normatively rejects liberal constitutionalism as a foreign-imposed and ultimately morally corrupting form of life 生活方 式. Following structuralist histories of legal thought, I argue that political constitutionalism in both of its above manifestations, and despite its insistence on the primacy of indigenous intellectual resources, in fact draws heavily on the theoretical vocabulary of fin de siècle EuroAmerican jurisprudence. This not only pertains to its anti-formalist and sociological methodology, but also its historicist belief in the particularity of national communities and their legal consciousness. This belief is made plausible by the widespread use of biologistic imagery, linguistic hypostatizations of the "organic" and "living," and a rhetoric of crisis that ostensibly vindicates a harsh authoritarianism to safeguard the juridical life of the nation. This hidden Euro-American genealogy inherent in Chinese neoconservatism also lays bare a striking disparity between the movement's normative agenda and its theoretical genesis. 
Consequently, in the final part of this article, I argue that Chinese political constitutionalism faces a number of theoretical antinomies and normative dilemmas. To begin with, the movement is troubled by an unresolved tension between its methodological and normative agenda, which leads to what I call a dilemma of scale. More problematic still, the movement is as much a by-product of the post-1989 globalization of constitutional thought as the normative methodology it purports to challenge - resulting in a dilemma of origin(ality). Glossing over the discrepancy between its agenda of national self-assertion and its own transnational theoretical origins, it cannot but commit a performative self-contradiction. Lastly, I suggest that political constitutionalism's nationalist rhetoric and cultural solipsism ends up undercutting its methodological insights, which manifests itself in a dilemma of rejectionism. In particular, the movement's hypostatization of Chinese cultural particularities leads it to juxtapose "local" and "global" in a way that belies its pragmatist insights. This uncompromising nativism also impedes a more plausible account of the open-ended and contingent nature of legal globalization as well as its potential for China.

\section{The Post-Cold War Condition and the Emergence of Political Constitutionalism}

Some of the intellectual drivers of political constitutionalism can be traced back to structural shifts in Chinese academia in the 1990s. Foremost was the demise of orthodox MarxismLeninism as an orchestrating ideology of Chinese constitutional debate. Recent research has stressed how Soviet legal institutions helped restore formal legality to Chinese politics in the early post-Mao period (Ip and Partlett, 2016: 464). Beyond mere institutional resilience, however, it is questionable to what extent Marxism-Leninism still provides a viable source for contemporary Chinese constitutional theorizing. Indeed, the emergence of political constitutionalism itself attests to the fact that - apart from a minority of older-generation scholars and party ideologues-Leninist thinking no longer carries persuasive power among Chinese legal theorists (He, 2012: 112; Cohen, 2019: 246). Notably, this also applies to younger, self-consciously avant-garde academics who are sympathetic to the political status quo and seek to rationalize it theoretically (Seppänen, 2016: 29, 45). In hindsight, the demise of MarxismLeninism is perhaps best demonstrated by the fact that today's scholars of political constitutionalism no longer use it as a theoretical guide in their accounts of "socialism with Chinese characteristics."

Chen Duanhong, for instance, distinguishes "socialism in the substantial sense of the absolute constitution"-which he defines with reference to Carl Schmitt as an existential "law 
of survival"- from "socialism in the sense of the relative constitution," as it is expressed in the written constitutional text. Despite "stressing the Chinese national condition, practice, and the agency and creativity of the people," socialism as a constitutional principle is ultimately reducible to "the concrete institutions" of the Chinese party-state (Chen Duanhong, 2008: 496). In Jiang Shigong's rendering, the notion of socialism is further diffused into "the brilliant political imagination of thousands of years of Chinese civilisation [which] successfully fills the spiritual vacuum left by the weakening of the Communist vision" (Jiang, 2018a: 17). All this appears to suggest that Marxism has degenerated into an empty signifier of Chinese political institutions and an officially sanctioned strategy of asserting cultural particularity. None of the leading Chinese theorists of political constitutionalism refers to Marxism from a methodological vantage point.

However, the consequential inclination on part of these academics to rely on other, nonLeninist sources for their constitutional elaboration of China's Leninist party-state is not merely a sign of idiosyncratic scholarly interest. Nor is it purely — although it is also that - a result of the compensatory search for "a more subtle argument" (Veg, 2019: 41). Rather, this intellectual state of affairs should be seen in the wider context of post-1989 ideological pluralism, which requires us to reconsider some of the structural shifts and generational dynamics in Chinese academia during this period. As Wang Hui has suggested, scholars who had returned from abroad contributed significantly to the structural transnationalization of knowledge production in the post-1989 Chinese academic sphere (Wang Hui, 2003: 142). Intellectual historians generally agree that this biographical shift also entailed a professionalization and diversification of Chinese academics as a social stratum (Xu, 2000: 177; Wang Hui, 2003: 144; Wang Chaohua, 2003). Prima facie, this trend toward academic liberalization and "outbound internationalization" (Roberts, 2017: 77) seems to contrast with the revived interest in indigenous intellectual traditions and the cultural assertiveness of Neo-Confucianism. At a time when China's integration into the capitalist world economy made it blatantly clear that an isolated analysis of its domestic condition was becoming increasingly unfeasible, cultural relativism and postmodernism first appeared on the Chinese scene (Wang Hui, 2003: 145, 161; Zhang Kuan, 2009; Xu, 2010: 69). However, these seemingly disparate and contradictory phenomena ought to be understood as intrinsic parts of the dialectic of convergence and fragmentation which characterizes the process of transnationalization. Cultural self-assertion and structural transnationalization are mutually reinforcing phenomena (Dirlik, 1996: 113; Wang Hui, 2003: 170, 184; Xu, 2010: 69). 
Legal scholarship has not been exempt from these trends. On the one hand, the Weberian process of academic professionalization was mirrored in legal scholarship by a quest for what Albert Chen referred to in an influential account of legal reforms in the 1990s as a "legal enlightenment." On the other hand, and in contrast to what Chen vividly described as the seemingly "unqualified embrace at face value of the discourse of reason, subjectivity, liberty, equality, rights, progress and modernization" (Albert Chen, 1999: 164), some were also beginning to debate postmodernism and its critique of Enlightenment universalism for the first time (Ji, 1996; Zhu, 1997). ${ }^{2}$ The intellectual trajectories of two prominent Chinese legal scholars attest to these diverging trends. Nothing epitomizes the development from orthodox Marxism-Leninism in the 1980s to the endorsement of a moderately liberal notion of the rule of law and human rights in the 1990s better than the work of Li Buyun, one of the architects of China's early legal reforms (Li Buyun, 1984, 2001 [1991]). ${ }^{3}$ Another, seemingly converse example is the work of Zhu Suli. Upon returning from extensive studies in the United States in the early 1990s, Zhu began employing a host of novel and cutting-edge theories in the study of Chinese law, ranging from systems theory and legal realism to Foucauldian genealogy ([Zhu], 1995; Zhu, 1997). Today, Zhu and his sociological approach, with its emphasis on epistemic localism and the pragmatist critique of legal transfers, are considered by many to have pioneered the contextual study of Chinese law in the vein of political constitutionalism (Li Zhongxia, 2011: 163). Notably in the work of Jiang Shigong, one of Zhu's most prolific intellectual followers, Zhu's "towering presence" has contributed to the emergence of a peculiar zeitgeist among conservative-leaning scholars that invokes both iconoclastic rhetoric and conservative political outlooks (Seppänen, 2016: 17, 48).

In retrospect, the 1990s thus was a time of contradictory trends in Chinese academia. Those years witnessed an unprecedented liberalization and pluralization of legal scholarship (Yu, 2009; Ji, 2009). At the same time, the late 1990s also saw the first heated discussion of markedly anti-pluralist thinkers such as Carl Schmitt, who would soon emerge as one of the intellectual patrons of the bourgeoning agenda of political constitutionalism (Zheng, 2017; Brang, 2020; Mitchell, 2020).

\section{A Sense of Crisis in the Mid-2000s: Challenging the Global (Neo-)Liberal Order?}

While the structural shifts in Chinese academia since the 1990s provided a facilitative environment for the formation of political constitutionalism as a scholarly agenda, its rise cannot be fully understood without also taking into account the widespread and at times extraordinary sense of crisis that began to haunt parts of the Chinese legal community around 
the mid-2000s. It is generally understood that political constitutionalism emerged in opposition to the prevailing normative and text-centered methodology in Chinese constitutional scholarship and its latent agenda of political liberalization and judicialization (Chen Duanhong, 2008: 501; Gao, 2009: 47; Jiang, 2010: 41). Notably, this liberalizing trend at the domestic level was driven in large parts by politico-judicial elites such as the Supreme People's Court (Ahl, 2019), and it unfolded in context of a post-Cold War agenda of global constitutionalism that likewise was "court-centric, legal-texted, and elite-focused" (Chang, 2019: 460). Understood as a "normative framework in measuring a nation state's legal development," post-1989 global constitutionalism can be said to lay "down the limits and frontiers on national constitutions and legal orders in a top-down fashion" (Bin Li, 2018: 62, 58). However, this should not blind us to the fact that global constitutionalism is above all an intellectual agenda of national elites, who use its vocabulary of institutional convergence strategically to promote certain political changes (see Shinar, 2019).

The profound impact of post-1989 constitutional globalization on domestic Chinese reform debates was welcomed by liberal scholars. In a 2004 lecture, for instance, He Weifang noted how, "in this age of globalization, China's institutional development is increasingly subject to influences from the external world and intertwined with other countries, especially developed countries" (He, 2012: 103). This global influence, according to He, had the effect of increasing the legitimacy of liberal constitutionalism, so that in "the present, the West's constitutional system is [. . .] almost universally recognized worldwide. [. . .] This has been particularly true after the 1990s. The legitimacy of constitutional government has been so widely recognized that it can be described with Francis Fukuyama's classic expression: the end of history" (107). This dynamic had a profound impact on the "concept of the sovereign state," as it was "increasingly acknowledged among countries that sovereignty should also be subject to certain restrictions" (113). These restrictions were to be enforced by the "expansion of judicial powers worldwide," which was bound to leave its imprint on China too (115).

In a revealing essay published roughly at the same time, prominent constitutional scholar Zhang Qianfan further conceptualized this liberalizing trend as involving, inter alia, a de-ideologized understanding of constitutional scholarship as a "relatively neutral positive science"; a turn from intellectual isolationism to the adoption of foreign experiences and theories; a shift of focus from abstract debates about the constitutional text to its implementation; as well as a turn from 'the 'people,' the 'state,' 'sovereignty,' and other macro-level notions" to "the constitutional rights of individuals" and their reflection in "individual cases" (Zhang Qianfan, 2005: 4). In summary, in the early 2000s Chinese liberals were describing an 
international situation that was geared toward the expansion of liberal rights doctrine, the judicialization of politics, and the gradual diminution of sovereign prerogatives - all of which were underpinned by an end-of-history-esque atmosphere of global convergence. There seemed to be little debate on whether China should embrace these trends.

Notably, this liberalizing trend of the early 2000s was not only an academic phenomenon visible in the inclination of most legal scholars to favor legal autonomy and judicial professionalism (see also Han, Lin, and Zheng, 2008); it also corresponded to important changes at the political-institutional level. In 2001, the Supreme People's Court spawned a sustained debate about the interpretation and enforcement of fundamental rights through civil litigation with its landmark Qi Yuling decision. ${ }^{4}$ In hindsight, after being repealed by the court itself in 2008, the decision "marks a failed attempt at self-authorization" on the part of a reformminded judicial elite (Ahl, 2019: 260). Nonetheless, it surely also encouraged liberal voices in academia to speak up for further reform. In 2004, a constitutional amendment was adopted which incorporated the clause that the "State respects and preserves human rights" into Article 33. For liberal scholars, this amendment was "not only a change in the text and idea of the constitution, [it] simultaneously also mark[ed] a major transformation of the research model of constitutional scholarship," reflecting "a substantial shift from the collective to the individual" (Zhang Qianfan, 2005: 3). For Zhang Qianfan, this prefigured nothing short of a wholesale abandonment of a "holistic" view of society in favor of "methodological individualism" (8).

In hindsight, the annus horribilis of 2008 marked a turning point and signaled that a nativist backlash on a political and academic level was underway both in China and globally (see Xu, 2010: 74; Peerenboom, 2015: 52; Béja, 2019: 203). Shortly after Wang Shengjun assumed leadership of the Supreme People's Court, the court issued a declaration to the effect that the "principles of the Qi Yuling case are no longer applied," formally bringing the judicialization drive to a halt (Kellogg, 2008). Along with a new state narrative critical of law as being unresponsive to societal needs, a sustained crackdown on civil rights lawyers (Pils, 2017: 258; Béja, 2019: 224), and a populist revival in judicial politics, this amounted to what Carl Minzner famously dubbed a "turn against law" under the late Hu Jintao leadership (Minzner, 2011). To be sure, most observers agree that the ascent of Xi Jinping was characterized by a return to a more "centralized" and "legalistic" form of governance (Peerenboom, 2015; Minzner, 2015; Zhang and Ginsburg, 2019). As regards the ideological rejection of the previously dominant liberal vocabulary of reform, however, there appears to have been a gradual devolution rather than a sudden break between the two administrations 
(Cohen, 2019). Academically, these developments have been accompanied by a steady trend toward the ideological rectification of intellectual life (Minzner, 2019).

It was against this political backdrop that a group of scholars emerged in the mid-2000s who were eager to provide not only a theoretically rich critique of the liberalizing trend, but also a vindication of the extant regime of party leadership. In the shadow of the global financial meltdown, several Chinese intellectuals with neoauthoritarian leanings began endorsing what historian $\mathrm{Xu}$ Jilin describes as form of statist historicism. Unlike the 1990s, when even advocates of "indigenization" and cultural conservatism were still attempting to mediate between universal values and local conditions, the mid-2000s saw the rise of a more polemical anti-Westernism that aimed at the vigorous assertion of particular lifeforms against a globalist ideology (Xu, 2010: 69). It is not entirely clear whether these intellectuals have merely jumped onto the bandwagon of a conservative backlash or helped foster it in the first place, as Sebastian Veg has recently suggested (Veg, 2019: 24). In any case, constitutional anti-formalism and a political-contextual reading of Chinese law now became the lowest common denominator of efforts at crafting a "Chinese" jurisprudence (Seppänen, 2018: 34). This agenda is reflected in the shared opposition to what one author calls a "judicialized constitutional globalism" (Liu, 2017: 133). Commonly understood as a driver of institutional Americanization, this impression of a global liberal hegemony led to a pervasive sense of crisis among more conservative legal scholars.

Chen Duanhong is often considered to have started the political constitutionalist project (Gao, 2014: 1). In 2007, Chen first wrote about the "political crisis of our time," which he portrayed as "globalization's neocolonial challenge to nation-state-building" (Chen Duanhong, 2007: 45). Symptomatic of a post-Cold War unipolar world order in which China was pushed to the marginal position of a persistent objector, Chen conceptually linked these international dynamics with a domestic crisis characterized by rampant marketization and widespread corruption (46). These disintegrating effects, caused by the "unstoppable wave" of globalization (47), Chen soon later associated with the spread of liberal constitutionalism: "China, like all other non-European states, has not evaded the attacks and exploitation of European imperialism, nor has it escaped from the laws of modernity as defined by European civilization. [. . .] A constitution is a law of national integration; constitutionalism must not disintegrate the nation and the state. Several naïve nations have been disintegrated by the lure of constitutionalism" (Chen Duanhong, 2008: 499). In a familiar move, Chen linked this "political crisis" to the methodological agenda of liberal scholars, which he contrasted with a counter-agenda of Chinese particularity: 
[Chinese] scholars increasingly came under the conceptual and systematic constrictions of Western textbooks; [they] want to copy everything mechanically 依样葫芦, but end up deviating from common sense and facts. Chinese constitutional scholars must learn to face the Chinese national condition. "Facing reality" does not simply mean that one should equate facts with norms; rather, the facts also have to be confirmed normatively. (Chen Duanhong, 2007: 150)

A similar agenda consisting of methodological critique, historical revisionism, and disciplinary polemics was eloquently put forward by Jiang Shigong. Like Chen, Jiang suggested that the dawn of liberal hegemony brought about a crisis of theoretical representation. In his best-known essay on China's unwritten constitution, Jiang thus argues that the divergence between text and reality in China's constitution is due not to insufficient implementation - as liberal scholars maintain (Zhang Qianfan, 2010) - but to the false representation of China's political reality within its written constitution: "Under the influence of constitutionalism developed in the Western Enlightenment tradition, in their process of nation-building, developing countries have been compelled to enact a written constitution in line with Western standards [...] neglecting the fact that a constitution is but the formal expression of real political organizations that emerge in a particular culture" (Jiang, 2010: 14). The hegemony of global constitutionalism as a normative agenda, Jiang suggests, has invariably driven modern Chinese constitutional development toward convergence "with international ideological standards, whether set by the Soviet Union or by the Western world" (Jiang, 2010: 14). In the face of an all-leveling and unifying legal globalization, the hallmark of constitutionalism is therefore understood by these theorists as the juridical safeguarding of national particularity - free of the coercive influences of Western dominance.

To be sure, there are notable differences in Jiang's and Chen's methodological outlook and account of the Chinese constitution. ${ }^{5}$ While Jiang has sought to inductively ascertain unwritten constitutional principles and conventions from a sociological reading of Chinese politics (Jiang, 2010), Chen has instead deduced his account of party leadership as China's "fundamental law" from a political reading of the preamble (Chen Duanhong, 2008: 494). Nonetheless, there is a common set of ideas underlying their writings. First, they both juxtapose Chinese experience and reality with a global normative model that they believe to be Westerndominated. Second, whereas the former is depicted as genuine and true-to-life, the latter is associated with an empty normativism that is removed from social reality. Third, they contend that "innovation in China's own scholarship lags behind the practical creativity of our people and the decisions of our statesmen" (Jiang, 2010: 43), and ascribe this theoretical aloofness to the blind following of Western scholarship by Chinese academics. Fourth, they follow the 
historicist premise that constitutions are self-expressions of particular cultural and political communities. "The theoretical task of political constitutionalism," according to Chen, is thus to provide an "interpretative framework for a people to understand their own political existence" (Chen Duanhong, 2012). Lastly, like other representatives of political constitutionalism (Gao, 2009; Gao, 2014; [Zhu], 2018: 28-29; Wei, 2018: 152), they argue that constitutional scholarship must follow a "realist" imperative and reject superficial textual normativity in favor of a constitutional theory that derives normativity from the factual conditions of the Chinese polity: ex facto jus oritur (Chen Duanhong, 2016: 6). This realist imperative also implies that, in Chen's words, "the leadership right of the Chinese Communist Party is the fundamental fact of the Chinese constitution" (Chen Duanhong, 2007: 152). Thereby, Jiang and Chen have effectively recast the notion of constitutional normativity from a textual to a supra-textual one: party leadership instead of judicialization.

While certainly being most outspoken, Jiang and Chen were not the only authors who felt uneasy in the face of this liberalizing trend. For instance, the late Deng Zhenglai expressed this sense of disorientation as a "paradigm crisis" of Chinese law (Deng, 2006: 100). Not only was Chinese legal research evolving in a global context characterized by the asymmetry between a dominant Western center and a non-Western periphery, but its complicity in promoting a Western notion of modernization in fact contributed to its self-induced paradigm crisis (Deng, 2006: 103). Notably, back in 2006, Deng was still arguing that the urgent questions of Chinese legal scholarship could no longer be addressed in an isolated way and lamenting the continued fallacy of thinking in categories of the sovereign national state (Deng, 2006: 101). A few years later, he had shifted his view and began advocating an identity-based turn of legal scholarship: "The changes of the international situation in recent years, particularly the global financial crisis that broke out in 2008, have given us yet another chance to deeply reflect upon the course of globalization and the international order led by the West. [. . . The construction of China's social order, including the construction of its legal system, ought to serve the cultural and political identity of China” (Deng, 2011: 149).

Related to the alleged gullibility of liberal Chinese academics, Zhu Suli too began suggesting in 2008 that there was a crisis of legal education, calling for a "Chinese standard" as opposed to a "Western standard." In contrast to the more toned-down critique he presented to an American audience two years before (Zhu, 2007: 546), Zhu now insisted that legal education ought to be "linked with contemporary China, and with the great revival of the Chinese nation and its peaceful rise" ([Zhu], 2008: 24). This he opposed to a bleak vision of "people who only believe in ideas in foreign books and do not trust their own life experience," 
and who thus turn into "slaves of a certain culture or ideology" (25). Notably, the impression that the Western model faced a mounting crisis was also shared by many Chinese liberals, who, like Gao Quanxi, began noting the widespread sense of a supposed bankruptcy of Western modernity — even if they did not agree with this contention (Gao, 2009: 57).

In hindsight, it is therefore more than a mere coincidence that this illiberal turn - and its intensification under the $\mathrm{Xi}$ leadership - arose in concurrence with a worldwide revival of authoritarianism, a calling into question of liberal notions of rights, and a widely perceived crisis of the liberal political order more generally. In an ideological sense, the illiberal backlash of the late 2000s could even be said to have paved the way for the 2018 amendment with its formal re-merging of party and state (Veg, 2019: 42). Conversely, bringing party leadership back into the operative text, the amendment seems to have retrospectively sanctioned some of the long-standing arguments of neoconservative jurists. ${ }^{6}$ At the very least, it "coincide[s] quite comfortably with Chen and Jiang's advocacy for a more clearly articulated Decisionist authority in the Party" (Mitchell, 2020: 248). The amendment not only did "away with the fiction of the division between the state and the Party" then (Béja, 2019: 221), it also confirmed one author's observation that the new administration "is trying to recast the intellectual premises on which the legal system is built," moving toward "an order of identity of state and society, an order on corporatist terms" (Pils, 2017: 259).

Although the basic scholarly agenda of political constitutionalism remains unchanged since the late 2000s, then, there can be little doubt that the "new era" has also seen a shift from hitherto mostly defensive rhetoric to a more assertive and radical critique of "Western" liberalism (e.g., Jiang, 2018a). This shift is clear in an explicit agenda of presenting, in the words of Wei Leijie, the Chinese model as an "institutional alternative to democratic governance for non-Western states" and an "entirely new rule of law civilization" (Wei, 2018: 155). Encouraged in part by a politicized reception of Teemu Ruskola's influential critique of Western representations of Chinese law as a form of "legal orientalism,"7 as well as an endorsement of their arguments in parts of international research (e.g., Peerenboom, 2012; Backer, 2014), political constitutionalists have set out to attempt an ambitious overhaul of inherited understandings of the Chinese legal tradition. Zhu Suli's account of China's "ancient constitution," elegantly integrating bottom-up sociological inquiry and political realism with contemporary polemic, is perhaps the most noteworthy example ([Zhu], 2018). Jiang Shigong too has radicalized his theses, arguing that "it can be said that modern history is a narrative of Western nations imposing their way of life on other nations" (Jiang, 2014: 203-4). This imposition began in the late Qing, Jiang suggests in another essay, when "traditional legal 
pluralism" characterized by the "unity of rites and law" 礼法合一 began being seen as unmodern and hence was replaced by what Jiang calls the “state-law-centrism” 国家法中心主 义 of modern European territorial states (Jiang, 2015: 19). Jiang leaves little doubt that "Western civilization's domination since the age of discoveries," of which the global hegemony of liberal constitutionalism is but the most recent expression, is coming to an end (Jiang, 2018a: 23). Political constitutionalism's recent turn to grand history is perhaps the most noteworthy shift of intellectual politics in the "new era." This novel historicist agenda is in equal parts cultural assertiveness, methodological critique, and disciplinary polemic against Chinese liberals, who are at once found guilty of an unwarranted "scholarly self-confidence" ([Zhu], 2018: 65) and the “"self-Orientalizing' mindset of followers” (Tian, 2018: 23).

\section{Reasserting Chinese Particularity: Recurring Argumentative Strategies}

It is clear that political constitutionalism's intellectual genealogy is intertwined with structural shifts in Chinese academia that evolved alongside and as a consequence of, rather than in strict opposition to, the post-Cold War ideological liberalization that is the object of its criticism. Put differently, political constitutionalism is itself an outgrowth of the academic "Westernization" that it portrays as China's intellectual nemesis. This is all the more evident if we consider the transnational origins of anti-formalist, organicist, and statist legal thought, which political constitutionalism freely draws upon to put forward its supposedly more genuine account of Chinese constitutional particularity.

This transnational context of political constitutionalism's intellectual emergence conspicuously contrasts with the way its adherents juxtapose "local" (Chinese) with "global" (Western) experience and ascribe a number of dichotomous features to both. Thus, the selfstyled opposition between political constitutionalism and its normative adversary, vividly described by Gao Quanxi (2014), is directly translated into a parallel opposition between a local Chinese condition that is believed to be true-to-life, and a global condition marked by an empty normativism (see also Wei, 2018: 148-49). Thereby, a certain political or methodological position is deliberately confused with a cultural-historical category or scale- "Western," "global"-in what constitutes "a rhetorical move the purpose of which is to classify these tendencies as culturally alien and inauthentic" (Kumm et al., 2017: 5). This local-global dichotomy in turn gives rise to two related scholarly agendas that oppose the adoption of the "global-liberal" constitutional agenda as either methodologically naïve and practically unfeasible - the critical-realist strategy — or as politically undesirable and culturally alien — the neoconservative strategy. ${ }^{8}$ 


\section{Two Scholarly Agendas: Critical-Realist and Neoconservative}

The critical-realist agenda is most closely associated with the work of Gao Quanxi. It casts doubt on the applicability of liberal constitutional thinking to China-not on normative, but on factual grounds (Brang, 2020: 145-51). This contextual approach harks back to the criticism of legal transplants first formulated by Zhu Suli (1995, 1997), who pioneered an understanding in China of legal institutions as being "embedded" in particular societies: "simply because of current Western institutions' ostensible success, we should not take them as a decontextualized standard when they are in fact embedded in and abstracted from particular historical and theoretical contexts" (Zhu, 2007: 557). In this reading, law is an eminently context-specific phenomenon. Hence, "transplanting the American model of judicial review [. . . ] would require transplanting the whole set of constitutional cultural beliefs that backs up and sustains the American constitutional system" (Liu, 2017: 134). Similarly, for Gao, who refers to his theoretical stance as a form of “organic structuralism”生命结构主义 (Gao, 2014: 4), constitutionalism is best understood as a "living' political skill” which cannot be mechanically transplanted (Gao, 2009: 7). Hence his critique of textualism: "The reason we criticize mainstream constitutional hermeneutics or normative constitutionalism is not that they are not forms of constitutional scholarship, but rather that they are not a Chinese form of constitutional scholarship. They [. . . ] disregard or forget the political nature of the Chinese constitution" (Gao, 2014: 15). Gao, and to a lesser extent also Chen Duanhong (2012), seem principally in favor of a "normative" methodology but do not believe in its transplantability. Rather, Gao reasons that a viable normative understanding "can only develop from the internal functioning of the political power of the Chinese constitution" (Gao, 2014: 18). Gao, in other words, is a "critical liberal" who carefully mediates between sociological context and universal values: "The problem resides in the question of whether we can actually develop from the hundredyear Chinese history of constitutionalism or its current constitutional system a normative method 规范性法则 that is based on China's local conditions 本土 but also shares in universal values" (Gao, 2014: 22).

Similar arguments have been put forward in international research. Some authors suggest that institutional borrowing is not a viable method for improving the current state of Chinese constitutionalism. In this reading, a realistic reform path would have to depart from China's "living constitution" and focus on intra-systemic checks on party leadership (see, among others, Backer, 2009; Peerenboom, 2012; He, 2014).

Oftentimes, this realist agenda is couched in a language of value neutrality (e.g., Zhu, 2007: 560). In Zhu Suli's unparalleled parlance, his institutional pragmatism is not "a show of 
pride" but a study in "experimental sociology" ([Zhu], 2018: 215). The putatively neutral claim to the "truth of institutional evolution" (128) aside, it is of course more than doubtful whether a separation of this methodological agenda from its normative implications is possible (or even intended). Given that political constitutionalists themselves reject mainstream textualism as amounting to a hidden liberal agenda, it is telling that many of them have turned a blind eye to or refuse to acknowledge the political consequences of their own contextualism. Notably, even someone as politically outspoken as Jiang Shigong presented his well-received account of China's unwritten constitution not as a "metaphysical or ideological" proposition, but as an inquiry into China's "effective constitution" that was driven by "a value-free stance in historical and empirical research" (Jiang, 2010: 15).

However, despite assurances to the contrary, this claim to value neutrality is clearly at odds with the culturalist and historicist rhetoric of Chinese neoconservatism. For instance, in contrast to his (initial) insistence on value neutrality, Jiang Shigong rejects "Western" methodology not merely on methodological but also on normative grounds as politically undesirable and alien to the Chinese tradition. If a constitution is understood as an expression of a particular culture, this easily leads to the view that the wholesale transfer of "foreign" political institutions would result not only in ineffective transplants but in moral degenerationmanifesting itself in a variety of phenomena such as the "mediocretization, vulgarization, and hedonization of intellectual culture" (Jiang, 2009: 26), or the spread of "social anomie" and political disorder (Jiang, 2015: 19). Hence, the uncritical reception of "the erroneous zone of Western concepts" on the rule of law and parliamentary democracy is seen as not only institutionally unfeasible, but morally "corrupting" (Jiang, 2018a: 16). Yet Jiang goes even further and effectively denies the very commensurability of "Western" and "Chinese" thought on epistemological grounds:

One important reason why Westerners have difficulty understanding the theories of the CCP is that their way of philosophical thinking has been constrained by the metaphysical tradition of the West. They are accustomed to a logical process that proceeds from concept to concept, and hence cannot truly understand the Chinese philosophical tradition of the 'unity of thought and action'. They cannot link up theoretical concepts with concrete historical practice, and cannot understand the unique interpretive strategies that the Chinese philosophical tradition has always employed. (Jiang, 2018a: 12)

Jiang's line of reasoning, reminiscent of the Derridean critique of "logocentrism," relies on the notion that there is a "radical difference" between "Western" and "Chinese" thought, and hence justifies an equally radical rejection of the former (see also Seppänen, 2020). Of course, by denying cross-cultural understanding as such —ironically through the employment of European 
poststructuralist theorems - the adherents of cultural particularism ineluctably commit a performative contradiction in the Habermasian sense (Habermas, 2002).

Chinese liberals, including proponents of political constitutionalism like Gao Quanxi, have been quick to exploit these inconsistencies (Gao, 2009: 69; see also Xu, 2010: 77-79). Gao's immanent critique of the political constitutionalist agenda provides an important corrective to culturalist excesses. Disconcertingly, however, he too uses similar rhetorical strategies when asserting the Chinese national condition over a lifeless globalism. Being entangled in a problematic tradition of organicist, statist, and historicist thought, these strategies are linguistically predisposed to denounce any deviating position not only on logical but also on aesthetic grounds: as un-Chinese, lifeless, or helplessly quixotic.

\section{Weimar Redux? Biologistic Imagery and the Rhetoric of Crisis}

Political constitutionalists employ a set of rhetorical strategies aimed at asserting the supposed vitality of China's particular constitution still untainted by the technocratic reasoning of liberal jurisprudence. In so doing, they have also adopted a theoretical vocabulary that is derived from global scholarly traditions as diverse as sociological jurisprudence and legal pluralism ([Zhu], 1995; Jiang, 2010, 2015); popular constitutionalism (Chen Duanhong, 2007: 148; Gao, 2009: 27); right-wing authoritarianism in the line of Carl Schmitt (see Zheng, 2017; Brang, 2020); and even geopolitical and spatial approaches to law (Jiang, 2018b; Wang Hui, 2018). Despite their obvious differences, these traditions can be said to form, in Duncan Kennedy's words, part of the "transnational legal consciousness" of the late nineteenth and early twentieth centuries. Famously summed up by Kennedy under the rubric of "the social," this transnational language was - not unlike political constitutionalism today-politically indeterminate and could take social-democratic, progressive, or fascist forms (Kennedy, 2006: 39). It had its roots in Hegelian historicism and the fin de siècle critique of nineteenth-century legal thought as being unresponsive to social needs. We can identify five traits that underpin the "social" critique of liberal legal thought, all of which reemerge in political constitutionalism's attack on normative methodology, thus unveiling its inherently global genealogy: anti-formalism, the rejection of methodological individualism, the normativity of the factual, the juridical life of the nation, and the rhetoric of crisis.

\section{Anti-Formalism}

The first is the idea that law should be interpreted according to its (social) purpose, which was initially put forward by Rudolf von Jhering in his polemics against "conceptual jurisprudence" 
and its pursuit of systematic coherence and deductive methodology (Jhering, 1992 [1872]: 64). It later culminated in sociological jurisprudence's criticism of "textual interpretative formalism," understood as a method that "refuses to vary meaning according to context" (Kennedy, 2001: 8634). Anti-formalist contextualism is now, as we have seen, reemployed by political constitutionalism against the Chinese normative mainstream which it charges with "mechanically" following foreign, and particularly American, doctrines in disregard of China's political reality. It was, however, also an American, Benjamin Cardozo, who warned in 1921 of "the demon of formalism [which] tempts the intellect with the lure of scientific order" (Cardozo, 1947 [1921]: 133), while another American, Roscoe Pound, polemicized against a "mechanical jurisprudence" characterized by "a rigid scheme of deductions from a priori conceptions" (Pound, 1908: 608). The result of context-indifferent legal formalism was, according to its European and American critics, a false sense of logical coherence detached from life—a "uniformity of oppression" (Cardozo, 1947 [1921]: 154).

Methodological anti-formalism informed fascist jurisprudence as well. Carl Schmitt maintained that legal norms had no validity outside the context of particular nation-states, and that textual normativism therefore ends up undermining the "concrete inner order" and "legal substance" of social institutions (Schmitt, 2006 [1934]: 11, 17). Both of these strands, however - the pragmatist and the fascist-possess a common root in Hegel's critique of Enlightenment universalism, which he ridiculed as a "fanaticism" and "intolerance towards everything particular" (Hegel, 1991 [1821]: 39). The very same antipathy to "abstract" uniformity now informs the Chinese critique of global constitutionalism as a rigid set of topdown rules implemented in apparent disregard of local particularities.

\section{Rejection of Methodological Individualism}

Although anti-formalism as such is politically indeterminate, the sociological critique of liberal jurisprudence was generally allied with a holistic social ontology. Georg Jellinek suggested in his 1900 magnum opus that "the difference in the principal views of the state can be ascribed to the difference between the two major worldviews: the individualistic-atomistic and the collectivist-universalist" (Jellinek, 1914 [1900]: 174). According to Martti Koskenniemi, this led to a division in European jurisprudence "into more or less individualist and communitarian streams, rationalist and historicist theories" (Koskenniemi, 2001: 262). "Social" jurists tended to side with the latter, following the historicist or pragmatist critique of enlightenment philosophy (Pound, 1908: 609, 1917: 204; Cardozo, 1947 [1921]: 109; Schmitt, 2006 [1934]: 38). Pound famously argued that, in the nineteenth century, "the conception of the abstract 
individual ruled in legal philosophy" (Pound, 1917: 218). This liberal notion of society as an "atomistic aggregate of individuals" (Hegel, 1991 [1821]: 311) was to be replaced by a sociology that derived normativity from concrete social "relations" (Pound, 1917: 212).

\section{Normativity of the Factual}

This "is-to-ought move" (Kennedy, 2006: 39) also had its roots in Hegel, who had infamously declared in his 1820 Philosophy of Right that "What is rational is actual; and what is actual is rational" (Hegel, 1991 [1921]: 20). Jellinek later reinterpreted this proposition from a psychological vantage point as "the normative power of the factual" (Jellinek, 1914 [1900]: 338), arguing that "the politically impossible cannot be subject to serious legal inquiry" (17). From there it was only a small step for Carl Schmitt to propose in 1928 that "whatever exists as a political entity is worth existing from the juridical point of view" (Schmitt, 2017 [1928]: 22, emphasis in the original). The same realist rationale now underlies political constitutionalism's insistence on party leadership as the supreme principle of China's constitution.

Hence, "today as well as in the foreseeable future, a rule of law without party leadership is by no means a viable choice" (Wei, 2018: 152). If this realist imperative is taken to an extreme, however, constitutional law risks turning into little more than an ontological glorification of the status quo, be it a Schmittian "existential law" of national integration (Chen Duanhong, 2008: $485,492)$ or "a law of necessity that upholds the state" ([Zhu], 2018: 29). Indeed, it is of secondary importance if this ex post juridical rationalization is achieved deductively, via a Schmitt-informed reading of the sovereign's "fundamental decision on [the nation's] future form of existence" (Chen Duanhong, 2016: 6); or inductively, via a sociological account of "institutional progress under the historical conditions pertaining at each time" ([Zhu], 2018: 217). In both cases, the underlying rationale is that "genuine" legal normativity is found not in the abstract and lifeless constitutional text, but in concrete social relations, namely the political leadership of the party (see also Jiang, 2015: 26).

\section{The Juridical Life of the Nation}

Historicist legal thought departed from Hegel's proposition that all nations are imbued with a peculiar "consciousness" and "emerge with their own particular and determinate principle, which has its interpretation and actuality in their constitution" (Hegel, 1991 [1821]: 373, emphasis in the original). For Hegel, such "a constitution is not simply made: it is the work of centuries" (313), giving rise to the intricate body of the state as the nation's moral "organism." 
Needless to say, "It is in the nature of an organism that all its parts must perish if they do not achieve identity and if one of them seeks independence" (290). Hence, the language of organicism shifted the task of jurisprudence from the textual "subsuming" of facts under norms to the corporatist "mediation" between and "integration" of different "collective entities" (Mannheim, 1964 [1927]: 494-96). It also, as Karl Mannheim has shown in his brilliant phenomenology of conservative thought, gave rise to an ethos of the concrete; to the "emphatic experience" of native "soil" and its "organic communities" (444); and to a quasi-aesthetical "impulse to emphasize the living other the conceptual" (483, emphasis in the original). Pragmatist thought was by no means exempt from this, leading Pound to speak of the "vigorous life" and "vitality" of the American common law tradition as opposed to a Romanized “scientific jurisprudence” which "decays into technicality” (Pound, 1908: 607, 615).

This lexicon of vitalism and organicism now permeates political constitutionalism in both its pragmatist and neoconservative form. As is well-known, already in the mid-1990s Zhu Suli began speaking of the need to rely on China’s “indigenous resources” 本土资源 for legal reform ([Zhu], 1995). Drawing on Hegelian vocabulary, Zhu declared that "it is the life of a nation that creates its laws, whereas legal scholarship can merely theorize upon them" (Zhu, 1997: 19). Chen Duanhong similarly speaks of China's "living constitution," which he claims is characterized by the "integration of state and society" and the "individual's assimilation 被 同化 into [...] the state" (Chen Duanhong, 2008: 501, 492). Paraphrasing Martin Heidegger, Chen conceives of "the written form of a constitution" as "the citizen's house of being" (Chen Duanhong, 2016: 9). Likewise, for Jiang Shigong the rule of law is infinitely more than a codified principle - it sanctions a "form of life" and requires an existential "belief" (Jiang, 2011: 40). Like Chen, Jiang postulates an “organic unity” 有机统一 between party and state (Jiang, 2018a: 12; see also Jiang, 2010: 24; Jiang, 2015: 22). More recently, in a throwback to Carl Schmitt's konkretes Ordnungsdenken and his polemic against abstract and rootless normativity, Jiang has embraced early twentieth-century geopolitical thought (Jiang, 2018b: 115). He writes that, "unlike the abstract thinking of universal philosophy, geography must always be concrete" (Jiang, 2018b: 120). Consequently, the legitimacy of the Communist Party is, in his view, a result of "its indigenous, national nature, its authentic Chinese nature," of it being "consistently grounded in this great native land" (Jiang, 2018a: 26). Strikingly, even self-proclaimed liberals like Gao Quanxi have endorsed the vocabulary of vitalism in their attack on methodological formalism. In a metaphor that seems to be borrowed from Jhering (1992 [1872]: 127), Gao refers to the "fruits" of constitutionalism, borne by the "large tree" of politics, which must be planted on fertile "soil" to grow healthily (Gao, 2009: 6-7). For Gao, "only indigenous norms 
内生的规范 bear full vitality and may ultimately “yield positive results' 开花结果” (Gao, 2014: 25).

\section{Rhetoric of Crisis}

We should not take the appropriation of organicist language lightly. After all, it is embedded in a rhetoric of crisis that harks back to the dark side of early twentieth-century avant-garde iconoclasm and easily lends itself to an intolerant authoritarianism. If what is at stake is no longer just a theoretical approach, but the very "lifeform" of an organic community, a "wrong" theory will not only lead to ill-founded propositions - it will also exert an "unhealthy" influence on the "social body" at large and threaten moral degeneration. In Weimar Germany, Schmitt famously hailed the supposedly healing effects of the "state of exception" which he contrasted with the ossification of a formalistic normativity no longer in line with the demands of the underlying political structure. "In the exception," he ominously wrote, "the power of real life breaks through the crust of a mechanism that has become torpid by repetition" (Schmitt, 2015 [1922]: 21). Surely, a lesson to be drawn from Weimar is not only that liberal institutions such as judicial review might not have prevented Nazi rule (see Gao, 2009: 25; [Zhu], 2018: 18), but also that the rhetoric of crisis tends to suppress debate instead of fostering critical engagement. As Reinhart Koselleck reminds us, the medieval theological notion of crisis was infused with a sense of historical fatalism when it was reapplied in the nineteenth century to perceived social decay. Such usage of the term tends to operate within a strict binary of alternatives which demands decisive action-something that is clearly detrimental to a balanced discussion and immunizes itself against external critique by resorting to "prophetic" language (Koselleck, 2006 [1986]: 207). "The organic doctrine," Jellinek pointed out, seeks to "cut off the discussion through a word of authority; instead of explaining, it contents itself with a metaphor" (Jellinek, 1914 [1900]: 156).

The vocabulary of crisis thus serves a predictable strategy, recasting a theoretical opposition between scholarly approaches as a quasi-aesthetical one (Seppänen, 2018: 34). Samuli Seppänen has suggested that underlying such uses might be a desire for an "aesthetically pleasing explanation for conflicting emotions about China and the West" (Seppänen, 2016: 163). Gao Quanxi similarly speaks of the "thrill” 快感 that comes with criticizing "Western" notions of the rule of law, which he describes as a form of political romanticism (Gao, 2009: 96). The language of vitalism, in other words, is an easy way of asserting one's theoretical position without much explanatory effort. "The most primitive form of fighting the rationalist-deductive mode of thought," writes Mannheim, "is by invoking life, juxtaposing the 'written constitution' 
with reality, which is always richer and more vital than the written word" (Mannheim, 1964 [1927]: 485, emphasis in the original). However, in 1920s Europe as much as in contemporary China, the language of national degeneration can be no more than an "aesthetical surrogate" for an actual lack of "consensus in worldviews" (Damler, 2012: 13).

Unsurprisingly, there was no lack in critics of the transnational consciousness of the "social," many of whom cast doubt on the existentialist hypostatization of state and society as "social organisms" (Kennedy, 2006: 60). The Neo-Kantian Hans Kelsen rejected the organicist conceptions of the state as "a meta-legal being" and "the precondition of law" (Kelsen, 1934: 116), depicting it as a form of juridical fantasizing caused by an "anthropomorphic-personifying legal language" (52). For Kelsen, such terminology was but a psychological by-product of the human inclination to look for sensuous representations of abstract ideas (120-21). Tellingly, it is not only political constitutionalism that draws extensively on the theoretical vocabulary of "social" jurisprudence - its liberal adversaries too draw on the arguments of the early critics of the sociological approach (e.g., Zhang Qianfan, 2005; Ji, 2006; Xu, 2010). This suggests that these vocabularies are indeed universal and transcultural. What is striking about constitutional debates in contemporary China, then, is perhaps less their specifically national character but their local reproduction of global ideological oppositions.

\section{The Antinomies of Legal Globalization: Three Dilemmas}

At the heart of the political constitutionalist project lies a series of unresolved dilemmas. These dilemmas are brought to the fore by the performative self-contradiction between the movement's pragmatist methodological tools and its neoconservative rhetoric; between its nationalist political vision and its transnational theoretical form; and between its prima facie rejectionist vision of legal globalization and the global sources of that very vision. These contradictions not only compromise the methodological insights of political constitutionalism, but also display some of the recurring antinomies inherent in the transnational spread of legal thinking, a process that can be characterized as a dialectic of convergence and fragmentation (Teubner, 1998; Law and Versteeg, 2011). On a more positive note, however, these antinomies also lend themselves to an immanent critique of the political constitutionalist agenda, and to "semi-peripheral" visions of legal globalization more generally.

\section{The Dilemma of Scale}

While it is evident that political constitutionalism asserts a nativist vision of the local as inherently worthy of preservation, it is much less clear what the scale of this local dimension 
is, and how it could be kept apart from the global. Underlying this dilemma of scale is an unresolved tension between the movement's pragmatist methodological tools and its neoconservative political goals. The most influential notion in the pragmatist defense of Chinese local particularities is undoubtedly that of "local knowledge." Drawing on Clifford Geertz, Zhu Suli famously sets "local custom" and "knowledge" against national legislation based on legal transplants of foreign law ([Zhu], 1995: 3). However, the rejection of the transfer of foreign law to China seems to be but a secondary concern for Zhu, one that is overarched by a more fundamental concern over top-down national legislation: "First, the knowledge needed for social action is at least to a large extent of a concrete and local nature. Hence, this local knowledge cannot apply universally 放之四海而皆准. Second, foreign experience cannot replace Chinese experience" (6).

While Zhu's elaborate localism has been highly influential in Chinese legal theory, it has also encountered criticism, including from scholars of political constitutionalism. Gao Quanxi points to the difficulty of determining the scale of what is to be seen as indigenous. Is it strictly local - that is, subnational-knowledge, as Zhu Suli implies, or is it a nationalcultural-historical essence associated with "Chinese-ness" (Gao, 2009: 65)? Similarly, Gao laments that the notion of "indigenous resources" is presented not only as a useful heuristic tool, but as a basis for an entire social theory. This bears the risk of essentialization, thereby "setting up a natural rift between what is 'indigenous' and what is 'alien'" (62). The dilemma of scale, in Gao's view, turns out to be based on an untenable dichotomy, since every social community is characterized by the interaction of indigenous and outside forces: "There are no indigenous resources or an absolute other 他者 in an abstract sense. Every strong, healthy, and vital social collective develops out of the interaction and competition with other social collectives" (63). In Gao's view, if foreign institutions or concepts take root in another social context, that itself is proof of their "organic vitality," which makes any juxtaposition with a supposedly more genuine indigenous resource obsolete (64). This also shows that the polemical juxtaposition of local and global, on which the neoconservative strand of political constitutionalism is based, stands on shaky ground (see also Deng, 2008: 124).

More problematic still, Gao's critique suggests that the Chinese champions of institutional pragmatism are inconsistent in their application of bottom-up sociological inquiry, including in their treatment of judicial review. Even after the citation of constitutional norms by the judiciary was outlawed, some local courts have in fact continued to interpret constitutional provisions in their adjudicatory practice. Daniel Sprick recently described this as a "low-key constitutional jurisprudence" (Sprick, 2019). In principle, taking the imperative of 
"institutional evolution" at face value, there is no apparent reason why constitutional adjudication as a bottom-up evolutionary process should fall outside its purview. Indeed, Gao Quanxi demonstrates that the vocabulary of contextualism and organicism is also applicable to the gradual indigenization of judicial review. Thus, in an interesting rebuttal, he recently portrayed further judicialization as a way of upholding the "life of the constitution" (Gao, 2018).

This goes to show that the legal vocabulary of the "social" lends support to contradictory projects, and need not serve as a rhetorical cloak over a neoconservative agenda alone. On the other hand, Chinese pragmatism's alliance with nationalist rhetoric may well lead into an intellectual cul-de-sac and end up impoverishing its insight into the open-endedness of institutional innovation. Once the constant appeal to the concrete life of the law turns into an uncompromising and dogmatic imperative, it becomes no less a lifeless abstraction than the constructive rationalism of Enlightenment thought (Mannheim, 1964 [1927]: 502). Perhaps unsurprisingly, then, while the sophisticated sociological accounts of Jiang, Zhu, and others have undoubtedly contributed to a realist understanding of how China's constitutional system works in practice, they have done remarkably little to identify actual legal limitations, in lieu of judicial checks, on very real executive power (Ding, 2017: 330; Brang, 2020: 145).

\section{The Dilemma of Origin(ality)}

A second and related dilemma is that of origin or originality. As shown above, political constitutionalism pursues a counter-agenda to the "blind" acceptance of foreign constitutional doctrines which aims at establishing a sui generis Chinese jurisprudence (e.g., Wei, 2018: 150). According to Jiang Shigong, "the rise of a global power needs to be accompanied by global thought" (Jiang, 2018b: 122). The aspirations and stakes are high in this theoretical project. It is doubtful, however, whether political constitutionalism can succeed in carrying out this selfdeclared mission. In this regard, it is useful to again refer to Duncan Kennedy's account of the globalization of legal thought. Drawing on Ferdinand de Saussure's structural linguistics, Kennedy invites us to think about legal globalization as a process in which a transnational langue is instantiated in local paroles: "We can distinguish two processes. There is that by which a transnational mode of thought comes into existence as jurists combine ideas with distinct origins, displacing a previous transnational mode. And the process of geographic diffusion of a transnational mode, [. . .] combining it with 'indigenous' elements, and the residuum of the previous mode, into a new national synthesis" (Kennedy, 2006: 23). Following Kennedy's linguistic analogy, we may rephrase the dilemma of originality along structuralist lines: Is political constitutionalism but a rearticulation of an inherited mode of transnational 
legal thinking—say, "social” jurisprudence—-merged with indigenous Chinese elements? Or is it an attempt to create a new transnational legal language? There can be little doubt that it is the former. Clearly, political constitutionalism is as much the outcome of a re-localization of global constitutional thought as its normative adversary. Since the nemesis of normativism is, in the minds of neoconservative scholars, associated with a Western-dominated judicial globalism, they position themselves as nativist defenders of Chinese intellectual particularity. Inasmuch as they rely on "foreign" intellectual sources to phrase their criticism, however, they nolens volens destabilize and transcend this very local-global-dichotomy.

Some liberal-leaning scholars associated with political constitutionalism have long pointed to this inconsistency in the neoconservative project of a national jurisprudence. There is no non-European modern society, Gao Quanxi contends, that has not been "Westernized" to some extent in the process of its "modernization." This inconsistency even extends, Gao maintains, to the critics of Westernization and hegemonic global legal culture, since they too can only expound such criticism on the very the basis of modernity (Gao, 2009: 59-60). Thus, Gao suggests, many of the sources of Chinese neoconservatism-"Huntington's clash of civilizations, Schmitt's friend-enemy-distinction, etc."-are decidedly "not intrinsic to the Eastern or Chinese tradition; they have also been transferred from the West." "In fact," Gao argues in an interesting reversal, "these theories of juxtaposing friend and enemy and the intellectual disposition [underpinning them] are incompatible with the Chinese tradition of the doctrine of the mean 中庸” (Gao, 2009: 95). Similarly, Xu Jilin suggests that the Chinese adherents of historicism reinforce an "imagined" notion of China that is as unrepresentative of the actual richness of its intellectual tradition as liberal democracy is of the "Western" tradition $(\mathrm{Xu}, 2010: 74,80)$. Conversely, their mystification of the state as a moral organism demanding absolute deference is no less an invention of "Western" modernity (Xu, 2010: 75-76). In an argument that recalls Jürgen Habermas' critique of postmodernism as a performative contradiction, liberal critics have long held that, while Chinese postmodernists make use of an increasingly global discourse of anti-modernism, they also reject the very institutional underpinnings that have enabled this discourse to globalize in the first place (Ji, 1996: 107; Gao, 2009: 69; Zhang Kuan, 2009: 155-56; Xu, 2010: 69). It may well be that "unreflective constitutional borrowing in judicial review undermines the political identity of the particular state" (Liu, 2017: 131). However, an unreflective nativism likewise tends to undermine the transcultural epistemic basis on which its critique is grounded.

The global spread of constitutional ideas, thus, does more than give rise to local countermovements that reassert the particularity of their respective political orders and legal 
communities. It also provides the argumentative strategies that local actors in "semi-peripheral" communities wield to criticize such global norms. In other words, it is a precondition for their criticism (Kennedy, 2006: 46-62). In line with this observation, many have pointed out that there currently seems to be "no richly-conceptualised alternative ideology with potential global appeal contesting the global constitutionalist grammar" (Kumm et al., 2017: 4; see also Dixon and Landau, 2019: 496; Cohen, 2019: 246). Moreover, national self-assertions through practices of (abusive) borrowing are far from new (Kumm et al., 2017: 9). As early as 1872, Jhering described Roman jurisprudence as "an alien law in a foreign tongue, introduced by scholars and only fully accessible to them," and he pointed to the "gaping rift [that] opened up between such a law and the national legal sentiment" (Jhering, 1992 [1872]: 139). Several decades later, Pound lamented that the intrusion of "Romanist prejudices" had corrupted the naturalness of the American common law tradition (Pound, 1917: 221). And in 1934, a fresh convert to Nazism by the name of Carl Schmitt would decry the "displacement" of "medieval Germanic thought" by the "abstract normativism" of "Roman law" and "liberal-constitutional" thinking, something he associated, to the horror of contemporary readers, with Judaism and its supposedly “uprooted” life experience (Schmitt, 2006 [1934]: 9).

What these instances show is that legal globalization constantly reproduces the opposing strategies of appealing to either global convergence or local particularity-strategies that evidently transcend the geographical and cultural division lines they are supposedly based upon. As Kennedy points out, even though jurists of the semi-periphery of global knowledge production tended to emphasize the uniqueness and particularity of their national experiences, "we are left with the question of why, at the moment of discovering national particularity, each nation discovered the same thing? [...] The ideology of the social was (perhaps) not a reflection of national particularity, but an instrument in the 'imagining' of presently nonexistent national communities" (Kennedy, 2006: 50, emphasis in the original). If we push this interpretation even further, the recent emergence of Chinese neoconservatism, just as with the reemergence of NeoConfucianism and cultural traditionalism in the 1990s, would appear to be yet another emotionally consequential but theoretically fruitless response to the structural dynamics of global economic and legal integration. Political constitutionalism thus reveals the paradoxes that surface if one asserts a national community that is at best imagined, all the while relying on a globalized language of critique — which is itself part of the phenomenon one seeks to reject. However, we can qualify this admittedly bleak conclusion which suggests there is little room for semi-peripheral agency and the critique of contemporary globalization other than tacit acquiescence or recourse to an apologetic nationalism. This, it seems to me, requires an 
immanent critique of the political constitutionalist agenda and an exploration of the sources of its paradoxes.

\section{The Dilemma of Rejectionism}

In 2008, the late Deng Zhenglai began to argue that most Chinese scholars, irrespective of their ideological persuasion, entertain the same "closed-off notion of globalization." This notion entails the belief that legal globalization is inevitable, homogenous, and unidirectional (Deng, 2008: 120). Hence, Deng maintained, this leads to the misconception that one must choose between exclusive alternatives: either passively accept this uniform wave of globalization (the liberal position), or reject it outright (the conservative or leftist position). Thus, although Deng repeatedly criticized Chinese liberals for uncritically following a "Western" paradigm of modernization, he equally called into doubt the purely rejectionist position of neoconservative anti-globalists:

Those theorists who hold an antagonistic or skeptical attitude toward "legal globalization" are more or less approaching the question from the status quo of political multipolarity and cultural pluralism and the need to defend the essential features 本质特征 of law/state sovereignty. Consequently, they are opposing globalism by resorting to "national character" or "localism." It is readily apparent that this is a relatively closed-off way of thinking. (Deng and Sun, 2008: 39)

Unlike the fatalism of both liberals and neoconservatives, Deng's vision of legal globalization is characterized by the dialectic unity of universalism and particularism; uniformity and pluralism; integration and fragmentation; internationalization and indigenization (Deng, 2008: 123). His remedy for the false dilemma of rejectionism, therefore, is what he refers to as a notion of globalization as an open, contingent, and heterogeneous process that allows for constant redefinition and contestation through discursive struggles (121-23). Such an openended notion of globalization does not necessarily deny the relative dominance and stability of a given transnational mode of legal thinking, but it urges Chinese scholars to identify potential margins of deviation and work toward the greatest possible degree of agency within a given structure, instead of simply rejecting or giving in to the status quo of a globalization that serves the interest of a particular group of people and states and marginalizes alternative visions (Deng, 2008: 126; see also Gao, 2009: 95).

Of course, the rhetoric of agency also lends itself to contradictory purposes. For “conservative liberals" like Gao Quanxi, stressing agency might be a way of mediating between universal values and national particularities (Gao, 2009: 95), or between the enduring ideals of American republicanism and the identity of Chinese liberals (Gao, 2015). For neoconservatives, on the other hand, stressing Chinese agency entails the vigorous assertion of a national counter- 
agenda to liberal constitutionalism (Wei, 2018: 155; Jiang, 2018a). Paradoxically, however, and in contrast to their prima facie rejectionist view of globalization, this politically illiberal agenda is made possible by a markedly liberal approach toward global theoretical sources. Whereas only a very narrow notion of what is "Chinese" is acceptable to its advocates, Chinese neoconservatism itself professes a pragmatist and postmodern anything-goes attitude when finding and recombining theoretical inspirations to support their claims (see, e.g., Zhu, 1997: 14). This eclecticism lends itself to a theoretical bricolage that makes it difficult to establish what exactly the intellectual sources of political constitutionalism are (see Li Zhongxia, 2011: 162; Gao and Tian, 2011: 75). More importantly, however, the movement's polemical antiglobalism also compromises its professed mission to promote theoretical agency and originality.

Likewise, the scholarly apology for political authoritarianism may very well backfire on Chinese neoconservatism. In particular, the recent trend toward ideological rectification undermines its own intellectually pluralist foundation. Without such pluralism, and the open intellectual climate that facilitates it, it is unclear how Chinese theoretical innovation could be feasible in practice (Seppänen, 2018: 36; Minzner, 2019). Equally troubling, the assertive hypostatization of national traditions compromises the rhetoric of agency and ends up reinforcing a problematic view of Chinese history as being caught in an ahistorical stasis (Dirlik, 1996: 114), eventually reproducing the same old "trans-valued Orientalist clichés" (Ruskola, 2013: 53). Hence, while the neoconservative champions of cultural assertiveness like to belittle the agency of their liberal peers, casting their agenda as a pitiful self-Orientalization, they themselves tend to rely on the essentialist vocabulary of Orientalism (Dirlik, 1996: 106-7). In contrast, by taking the question of semi-peripheral agency seriously instead of merely using it as a rhetorical tool, one would have to understand legal globalization as the outcome of strategic choices of "local" actors, rather than as a wave of sinister forces entirely beyond human reach.

\section{Conclusion: The Semi-Periphery Talks Back—But What Does It Have to Say?}

Contemporary China, in the words of one scholar, epitomizes both "the powerful impulse towards, and the formidable limits to, cosmopolitan constitutionalism" (Patapan, 2015: 96). This article has interpreted Chinese political constitutionalism as an attempt to challenge the post-Cold War agenda of global constitutionalism and described some of the dilemmas and paradoxes encountered in this process. Chinese theorists are increasingly outspoken in presenting China's party-state as a systemic competitor of "Western" liberal constitutionalism. If successful, this assertiveness might entail a shift and potential reversal in the transnational flow of constitutional ideas from the center to the (semi-)periphery (see Roberts, 2017: 16). 
Indeed, some point to the influence already exerted by the Chinese model on different strands of constitutional authoritarianism (Dixon and Landau, 2019: 491). However, while we cannot rule out the rise of a global legal culture "with Chinese characteristics," it is less clear if that would also entail a new "mode" of legal-constitutional thought—as suggested by some of its proponents - or rather a revival of old ideas for new purposes.

Notably, the newfound assertiveness of Chinese legal theorists since the mid-2000s has coincided with the crisis and disintegration of the post-Cold War liberal order and "the decay of 'the West' as a relatively cohesive geopolitical configuration anchoring a normative model of global order" (Kumm et al., 2017: 2). At the same time, the long-held belief among scholars of comparative and global constitutionalism concerning the progressive convergence of legal orders upon a vaguely liberal model has been shaken by theoretical and empirical objections (e.g., Law and Versteeg, 2011: 1171). Increasingly, the dynamic of institutional convergence has found its evil twin in the worldwide trend toward authoritarianism, anti-elitism, and constitutional backsliding. These phenomena can also be interpreted as a response, however illfounded, to the nexus of judicial elitism and economic neoliberalization accompanying postCold War global constitutionalism (among many, see Harvey, 2005; Slobodian, 2018; Tushnet, 2019). Arguably, these developments have been detrimental to local institutional innovation and popular participation (Unger, 2015: 36; Chang, 2019: 455).

Seen in this context, Chinese political constitutionalism might appear like a legitimate counterbalancing call for the re-politicization of a global constitutional orthodoxy. However, the danger of romanticizing this nativist backlash as a heroic self-assertion in the face of Western domination is as evident as its underlying rationale is unconvincing. After all, as Minzner notes, "China's shift against law is [. . .] an indigenous rejection by Chinese leaders of their own reforms, not of externally imposed ones" (Minzner, 2011: 968). Hailing every particularistic attack on global norms as local emancipation not only blurs the contribution that scholars of the Global South themselves have made to the universalization of these norms (Becker Lorca, 2012), but also serves to vindicate the suppression of local actors questioning the power of their respective elites by invoking global vocabularies (Kumm, 2018: 198). This result is not only analytically questionable; it also belies the initially emancipatory aspirations associated with the critique of Eurocentrism.

Indeed, the emergence of Chinese neoconservatism is a bleak reminder of the dangers inherent in a one-sided critique of constitutional globalization-the potential turn from emancipation to apology. At the same time, however, the dilemmas encountered in the assertion of Chinese national particularity have also prompted an immanent rethinking of the political 
constitutionalist agenda. This might set the stage for a less fatalistic critique of globalization from a Chinese perspective; one that stresses not incommensurable national communities and their legal consciousness, but transcultural argumentative strategies and forms of social hierarchy. Such a view, which sees local institutional change not only as an expression of national spirit or external imposition, but primarily as an outcome of strategic choices, might also be a more reliable guide for non-Western agency in our globalized present. This, however, would require that political constitutionalism radicalize its methodological insights and embrace the fragmented and open-ended structure of legal globalization — not as a given, but as a site of constant contestation between different political visions.

\section{Funding}

This project has received funding from the European Union's Horizon 2020 research and innovation program under the Marie Skłodowska-Curie Grant Agreement No. 713600. 


\section{Notes}

1. Most Chinese accounts make a further distinction between normative and hermeneutic approaches (Li Zhongxia, 2011; Gao, 2014: 2-3), although both approaches agree on the primacy of textual analysis and the autonomy of legal reasoning as a normative, nonempirical discipline (Han, Lin, and Zheng, 2008: 135).

2. Notably, Chen concluded that the postmodern critique of China's mainstream jurisprudence misses the point, which is to work toward the establishment of a legal system at a most basic level, not its avant-garde critique (Albert Chen, 1999: 164). A similar point was made by Chinese liberals such as Ji Weidong (Ji, 1996: 106).

3. See Seppänen, 2016: 115-21, for an account of Li's scholarly trajectory.

4. In this case, plaintiff Qi Yuling sued defendant Chen Xiaoqi and claimed damages on grounds of identity theft. Chen had appropriated Qi's school examination results, went on to study at college and even took up employment under her name. To much surprise, upon request by the Higher People's Court of Shandong, the Supreme People's Court found in its official reply 批 复 that Chen had thereby also, as asserted by Qi, infringed upon her constitutional right to education under Article 46. Owing in part to the initiative of judge Huang Songyou, who was later ousted on corruption charges, this marked the first time that constitutional rights were deemed applicable in court, if only in civil litigation (Kellogg, 2009: 231).

5. For more in-depth studies of Jiang and Chen, see Backer, 2014; Zheng Qi, 2017; Brang, 2020. 6. Apart from inserting "the leadership of the Communist Party of China" into Article 1, paragraph 2, of the constitution and calling it the "defining feature of socialism with Chinese characteristics" (thus rendering the academic debate about the preamble's legal force largely irrelevant), the most momentous changes introduced by the amendment are the abolishment of the state president's term limit (formerly stipulated in Article 79, paragraph 3) and the introduction of Articles 123-127, which regulate the newly set up State Supervision Commission and its local branches as separate state organs vested with potentially far-reaching powers of disciplinary supervision, investigation, and prosecution (Cohen, 2019: 242).

7. The Chinese debate on legal Orientalism is discussed in Zhang Taisu, 2019, and Clarke, 2020. 8. Zhang Taisu (2019: 250) has similarly identified "pragmatism" and "nationalism" as the two central "ideological forces" in the rejection of legal transfers in modern Chinese history. 


\section{References}

AHL, BJÖRN (2019) "Judicialization in authoritarian regimes: the expansion of powers of the Chinese Supreme People's Court.” International J. of Constitutional Law 17, 1: 252-77.

BACKER, LARRY CATÁ (2009) “The party as polity, the Communist Party, and the Chinese constitutional state: a theory of state-party constitutionalism." J. of Chinese and Comparative Law 16, 1: 101-58.

BACKER, LARRY CATÁ (2014) “Toward a robust theory of the Chinese constitutional state: between formalism and legitimacy in Jiang Shigong's constitutionalism.” Modern China 40, 2: 168-95.

BECKER LORCA, ARNULF (2012) "Eurocentrism in the history of international law." Pp. 1034-57 in Bardo Fassbender and Anne Peters (eds.), The Oxford Handbook of the History of International Law. Oxford: Oxford Univ. Press.

BÉJA, JEAN-PHILIPPE (2019) “Xi Jinping's China: on the road to neo-totalitarianism.” Social Research 86, 1: 203-30.

BRANG, LUCAS (2020) "Carl Schmitt and the evolution of Chinese constitutional theory: conceptual transfer and the unexpected paths of legal globalisation." Global Constitutionalism 9, 1: 117-54.

CARDOZO, BENJAMIN NATHAN (1947 [1921]) “The nature of the judicial process." Pp. 107-84 in Selected Writings of Benjamin Nathan Cardozo. New York: Fallon Publications.

CHANG, WEN-CHEN (2019) "Back into the political? Rethinking judicial, legal, and transnational constitutionalism." International J. of Constitutional Law 17, 2: 453-60.

CHEN, ALBERT (1999) "Toward a legal enlightenment: discussions in contemporary China on the rule of law." Pacific Basin Law J. 17: 125-65.

CHEN, ALBERT (2014) "The discourse of political constitutionalism in contemporary China: Gao Quanxi’s studies on China’s political constitution.” China Rev. 14, 2: 183-214.

CHEN DUANHONG 陈端洪 (2007) 宪制与主权 (Constitution and sovereignty). Beijing: 法 律出版社.

CHEN DUANHONG (2008) “论宪法作为国家的根本法与高级法” (On the constitution as the fundamental law and the highest law of the state). 中外法学 20: 485-511.

CHEN DUANHONG (2012) “宪法学研究中的政治逻辑” (The political logic in constitutional scholarship). http://www.calaw.cn/article/default.asp?id=8004. 
CHEN DUANHONG (2016) “宪法的法律性阐释及证立” (Explanation and demonstration of the legal character of the constitution). 清华法学 10: 5-25.

CLARKE, DONALD C. (2020) “Anti anti-Orientalism, or is Chinese law different?” American J. of Comparative Law 68, 1 (Mar.): 55-94.

COHEN, JEROME (2019) "Law's relation to political power in China: a backward transition." Social Research 86, 1: 231-51.

DAMLER, DANIEL (2012) Der Staat der klassischen Moderne. Berlin: Duncker und Humblot. DENG ZHENGLAI 邓正来 (2006) “中国法律哲学当下基本使命的前提性分析” (An analysis of the premises of the fundamental mission of contemporary Chinese legal philosophy). 法学研究 5: 99-110.

DENG ZHENGLAI (2008) “两种法学全球化观一一中国将何去何从?” (Two views of legal globalization: Which course will China follow?). 法学家 5: 118-26.

DENG ZHENGLAI (2011) ““世界结构”与中国法学的时代使命一《《中国法学向何处去》 第二版序” (The “global structure” and the historical mission of Chinese jurisprudence: preface to the second edition of "Whiter Chinese Jurisprudence"). 开放时代 1: 146-52.

DENG ZHENGLAI and SUN GUODONG 孙国东 (2008) “全球化, 文化政治与法律哲学一 一与邓正来先生谈中国法学的“全球化论辩” (Globalization, cultural politics, and legal philosophy: discussing the "globalization debate" of Chinese jurisprudence with Professor Deng Zhenglai). 东方法学 1: 31-40.

DING, XIAODONG (2017) "Law according to the Chinese Communist Party: constitutionalism and socialist rule of law." Modern China 43, 3: 322-52.

DIRLIK, ARIF (1996) "Chinese history and the question of orientalism." History and Theory 35, 4: 96-118.

DIXON, ROSALIND and DAVID LANDAU (2019) "1989-2019: from democratic to abusive constitutional borrowing." International J. of Constitutional Law 17, 2: 489-96.

GAO QUANXI 高全喜 (2009) 从非常政治到日常政治 (From constitutional politics to normal politics). Beijing: 中国法制出版社.

GAO QUANXI (2014) 政治宪法学纲要 (Outline of political constitutionalism). Beijing: 中 央编译出版社.

GAO QUANXI (2015) “政治宪法学的新世界主义视角” (The new globalist outlook of political constitutionalism). 探索与争鸣 5: 74-78. 
GAO QUANXI (2018) “宪法的生命在于实施” (The life of the constitution resides in its implementation). 民主与科学 1: 6-8.

GAO QUANXI and TIAN FEILONG 田飞龙 (2011) “政治宪法学的问题、定位与方法” (The problem, position, and method of political constitutionalism). 苏州大学学报 4: 7280.

HABERMAS, JÜRGEN (2002) "Universalisierungsanspruch und performativer Widerspruch.” Pp.159-82 in Uwe Wirth (ed.), Performanz. Zwischen Sprachphilosophie und Kulturwissenschaften. Frankfurt a.M.: Suhrkamp.

HAN DAYUAN 韩大元, LIN LAIFAN 林来梵, and ZHENG LEI 郑䂞 (2008) “宪法解释学 与规范宪法学的对话” (Constitutional hermeneutics and normative constitutionalism in conversation). 浙江学刊 2: 134-43.

HARVEY, DAVID (2005) A Brief History of Neoliberalism. Oxford: Oxford Univ. Press.

HE WEIFANG (2012) In the Name of Justice: Striving for the Rule of Law in China. Washington, DC: Brookings Institution Press.

HE, XIN (2014) “The party's leadership as a living constitution in China.” Pp.145-64 in Tom Ginsburg and Alberto Simpser (eds.), Constitutions in Authoritarian Regimes. Cambridge: Cambridge Univ. Press.

HEGEL, GEORG WILHELM FRIEDRICH (1991 [1821]) Elements of the Philosophy of Right. H. B. Nisbet, trans. Cambridge: Cambridge Univ. Press.

IP, ERIC and WILLIAM PARTLETT (2016) “Is socialist law really dead?" New York Univ. J. of International Law and Politics 48, 2: 463-511.

JELLINEK, GEORG (1914 [1900]) Allgemeine Staatslehre. Berlin: O. Häring. JHERING, RUDOLF VON (1992 [1872]) Der Kampf ums Recht. Berlin: Propyläen Verlag. JI WEIDONG 季卫东 (1996) “面向二十一世纪的法与社会“ (Law and society facing the twenty-first century). 中国社会科学 3: 104-13.

JI WEIDONG (2006) “施米特憲法學說的睿智與偏見” (Wisdom and prejudice in Schmitt’s constitutional theory).二十一世紀 94: 4-12.

JI WEIDONG (2009) "“To take the law as the public': the diversification of society and legal discourse in contemporary China." Pp.125-40 in Stéphanie Balme and Michael W. Dowdle (eds.), Building Constitutionalism in China. New York: Palgrave Macmillan.

JIANG SHIGONG 强世功 (2009) “民主, 如何是好” (How can democracy work?). 读书 5: 20-27. 
JIANG, SHIGONG (2010) "Written and unwritten constitutions: a new approach to the study of constitutional government in China." Modern China 36, 1: 12-46.

JIANG SHIGONG 强世功 (2011) “革命与法治: 中国道路的理解” (Revolution and rule of law: understanding the Chinese path). 文化纵横 6: 36-42.

JIANG, SHIGONG (2014) "How to explore the Chinese path to constitutionalism? A response to Larry Catá Backer.” Modern China 40, 2: 196-213.

JIANG SHIGONG 强世功 (2015) “党章与宪法: 多元一体法治共和国的建构” (Party statue and constitution: the construction of a plural but integrated rule of law republic). 文化纵 横 4: 18-29.

JIANG SHIGONG (2018a) “哲学与历史: 从党的十九大报告解读“习近平时代” (Philosophy and history: an interpretation of the Xi Jinping era from the viewpoint of the 19th CPC National Congress report). 开 放 时代 1: 11-31. English trans.: https://www.readingthechinadream.com/jiang-shigong-philosophy-and-history.html https://www.thechinastory.org/cot/jiang-shigong-on-philosophy-and-historyinterpreting-the-xi-jinping-era-through-xis-report-to-the-nineteenth-national-congressof-the-ccp/.

JIANG SHIGONG (2018b) “陆地与海洋——“空间革命”与世界历史的“麦金德时代”” (Land and sea: “spatial revolution" and the "Mackinder age" of world history). 开放时 代 6: 103-27.

KELLOGG, THOMAS (2008) “The death of constitutional litigation in China?" China Brief 9. https://jamestown.org/program/the-death-of-constitutional-litigation-in-china/.

KELLOGG, THOMAS (2009) "Constitutionalism with Chinese characteristics? Constitutional development and civil litigation in China.” International J. of Constitutional Law 7, 2: $215-46$.

KELSEN, HANS (1934) Reine Rechtslehre. Leipzig: Franz Deuticke.

KENNEDY, DUNCAN (2001) “Legal formalism.” Pp. 8634-38 in Neil J. Smelser and Paul B. Baltes (eds.), International Encyclopedia of the Social \& Behavioral Sciences. Amsterdam: Elsevier.

KENNEDY, DUNCAN (2006) "Three globalizations of law and legal thought: 1850-2000." Pp.19-73 in David Trubek and Alvaro Santos (eds.), The New Law and Economic Development: A Critical Appraisal. Cambridge: Cambridge Univ. Press.

KOSELLECK, REINHART (2006 [1986]) “Einige Fragen an die Begriffsgeschichte von 'Krise.'” Pp. 203-17 in Begriffsgeschichten. Frankfurt a.M.: Suhrkamp. 
KOSKENNIEMI, MARTTI (2001) The Gentle Civilizer of Nations: The Rise and Fall of International Law 1870-1960. Cambridge: Cambridge Univ. Press.

KUMM, MATTIAS (2018) "On the history and theory of global constitutionalism.” Pp.168200 in Takao Suami, Anne Peters, Dimitri Vanoverbeke, and Mattias Kumm (eds.), Global Constitutionalism from European and East Asian Perspectives. Cambridge: Cambridge Univ. Press.

KUMM, MATTIAS, JONATHAN HAVERCROFT, JEFFREY DUNOFF, and ANTJE WIENER (2017) "Editorial: The end of 'the West' and the future of global constitutionalism." Global Constitutionalism 6, 1: 1-11.

LAW, DAVID and MILA VERSTEEG (2011) "The evolution and ideology of global constitutionalism.” California Law Rev. 99, 5: 1163-1252.

LI, BIN (2018) “China's socialist rule of law and global constitutionalism” Pp. 58-99 in Takao Suami, Anne Peters, Dimitri Vanoverbeke, and Mattias Kumm (eds.), Global Constitutionalism from European and East Asian Perspectives. Cambridge: Cambridge Univ. Press.

LI BUYUN 李步云 (1984) 新宪法简论 (Treatise on the new constitution). Beijing: 法律出版 社.

LI BUYUN (2001 [1991]) "Human rights: three existential forms" Pp. 333-43 in Stephen Angle and Marina Svensson (eds.), The Chinese Human Rights Reader: Documents and Commentary, 1900-2000. Armonk, NY: M.E. Sharpe.

LI ZHONGXIA 李忠夏 (2011) “中国宪法学方法论反思” (Reflections on the methodological debate in Chinese constitutional scholarship). 法学研究 2: 160-72.

LIU, HAN (2017) "Carl Schmitt redux: law and the political in contemporary global constitutionalism.” Pp. 121-35 in Kai Marchal and Carl K. Y. Shaw (eds.), Carl Schmitt and Leo Strauss in the Chinese-Speaking World. Lanham, MD: Lexington Books.

MANNHEIM, KARL (1964 [1927]) "Das konservative Denken.” Pp. 408-508 in Wissenssoziologie. Berlin: Luchterhand.

MINZNER, CARL (2011) “China's turn against law.” American J. of Comparative Law 59, 4: 935-84.

MINZNER, CARL (2015) "Legal reform in the Xi Jinping era." Asia Policy 20: 4-9.

MINZNER, CARL (2019) "Intelligentsia in the crosshairs: Xi Jinping's ideological rectification of higher education in China." China Leadership Monitor 62. https://www.prcleader.org/carl-minzner. 
MITCHELL, RYAN MARTINEZ (2020) "Chinese receptions of Carl Schmitt since 1929." Penn State J. of Law and International Affairs 8, 1: 181-263.

PATAPAN, HAIG (2015) "Towards a cosmopolitan constitutionalism: on universalism and particularism in Chinese constitutionalism.” Chinese J. of Comparative Law 3, 1: 78-96. PEERENBOOM, RANDALL (2012) “Social foundations of China's living constitution.” Pp. 138-63 in Tom Ginsburg (ed.), Comparative Constitutional Design. Cambridge: Cambridge Univ. Press.

PEERENBOOM, RANDALL (2015) "Fly high the banner of socialist rule of law with Chinese characteristics! What does the $4^{\text {th }}$ Plenum decision mean for legal reforms in China?" Hague J. of the Rule of Law 7: 49-74.

PILS, EVA (2017) “The party and the law.” Pp. 248-65 in Willy Lam (ed.), Routledge Handbook of the Chinese Communist Party. London: Routledge.

POUND, ROSCOE (1908) “Mechanical jurisprudence.” Columbia Law Rev. 8, 8: 605-23.

POUND, ROSCOE (1917) “The end of law as developed in juristic thought, II." Harvard Law Rev. 30, 3: 201-25.

ROBERTS, ANTHEA (2017) Is International Law International? Oxford: Oxford Univ. Press. RUSKOLA, TEEMU (2013) Legal Orientalism. Cambridge, MA: Harvard Univ. Press.

SCHMITT, CARL (2006 [1934]) Über die drei Arten des rechtswissenschaftlichen Denkens. $3^{\text {rd }}$ ed. Berlin: Duncker und Humblot.

SCHMITT, CARL (2015 [1922]) Politische Theologie. 10 ${ }^{\text {th }}$ ed. Berlin: Duncker und Humblot. SCHMITT, CARL (2017 [1928]) Verfassungslehre. $11^{\text {th }}$ ed. Berlin: Duncker und Humblot.

SEPPÄNEN, SAMULI (2016) Ideological Conflict and the Rule of Law in Contemporary China: Useful Paradoxes. Cambridge: Cambridge Univ. Press.

SEPPÄNEN, SAMULI (2018) "Anti-formalism and the pre-ordained birth of Chinese jurisprudence." China Perspective 4: 31-38.

SEPPÄNEN, SAMULI (2020) “After difference: a meta-comparative study of Chinese encounters with foreign comparative law.” American J. of Comparative Law 68, 1: 186221.

SHINAR, ADAM (2019) "The ideologies of global constitutionalism." Global Constitutionalism 8, 1: 12-28.

SLOBODIAN, QUINN (2018) Globalists: The End of Empire and the Birth of Neoliberalism. Cambridge, MA: Harvard Univ. Press.

SPRICK, DANIEL (2019) "Judicialization of the Chinese constitution revisited: empirical evidence from court data." China Rev. 19, 2: 41-67. 
TEUBNER, GUNTHER (1998) "Legal irritants: good faith in British law or how unifying law ends up in new divergences." Modern Law Rev. 61, 1: 11-32.

TIAN FEILONG 田飞龙 (2018) “东方法律主义与中国法的重塑” (Legal orientalism and the reconstruction of Chinese law). 上海政法学院学报 2: 21-23.

TUSHNET, MARK (2019) "The globalisation of constitutional law as a weakly neo-liberal project." Global Constitutionalism 8, 1: 29-39.

UNGER, ROBERTO MANGABEIRA (2015) The Critical Legal Studies Movement: Another Time, A Greater Task. New York: Verso.

VEG, SEBASTIAN (2019) "The rise of China's statist intellectuals: law, sovereignty, and 'repoliticization."' China J. 82: 23-45.

WANG, CHAOHUA (2003) One China, Many Paths. New York: Verso.

WANG HUI (2003) China's New Order. Theodore Huters trans. Cambridge, MA: Harvard Univ. Press.

WANG HUI 汪晖 (2018) “作为思想对象的二十世纪中国(下)——空间革命、横向时间与 置换的政治” (Twentieth-century China as an object of thought (II): spatial revolution, horizontal time and the politics of replacement). 开放时代 6: 56-78.

WEI LEIJIE 魏䂞杰 (2018) “东方法律主义的中国意涵“ (Legal orientalism’s implications for China). 开放时代 6: 144-57.

XU JILIN (2000) "The fate of an enlightenment: twenty years in the Chinese intellectual sphere (1978-98)." East Asian History 20: 169-86.

XU JILIN 徐纪霖 (2010) “普世文明, 还是中国价值?一一近十年中国的历史主义思潮” (Universal civilization or Chinese values? Chinese historicism in the last decade). 开放 时代 5: 66-82.

YU XINGZHONG (2009) "Western constitutional ideas and constitutional discourse in China, 1978-2005.” Pp. 111-24 in Stéphanie Balme and Michael W. Dowdle (eds.), Building Constitutionalism in China. New York: Palgrave Macmillan.

ZHANG KUAN (2009) "The dilemma of postcolonial criticism in contemporary China." ARIEL: A Rev. of International English Literature 40, 1: 143-59.

ZHANG QIANFAN 张千帆 (2005) “从“人民主权”到“人权”一一中国宪法学研究模式的变 迁” (From "people's sovereignty" to "human rights": changes in the research model of Chinese constitutional scholarship). 政法论坛 23: 3-9. 
ZHANG, QIANFAN (2010) "A constitution without constitutionalism? The paths of constitutional development in China." International J. of Constitutional Law 8, 4: 95076.

ZHANG, TAISU (2019) “The development of comparative law in modern China.” Pp. 228-51 in Mathias Reimann and Reinhard Zimmermann (eds.), Oxford Handbook of Comparative Law. 2nd ed. Oxford: Oxford Univ. Press.

ZHANG, TAISU and TOM GINSBURG (2019) “China's turn toward law." Virginia J. of International Law 59: 307-89.

ZHENG, QI (2017) "Chinese political constitutionalism and Carl Schmitt.” Carl Schmitt Studien 1: 43-54.

[ZHU] SU LI 苏力 (1995) “变法, 法治建设及其本土资源” (Institutional reform, the construction of the rule of law, and its indigenous resources). 中外法学 41: 1-9.

ZHU SULI 朱苏力 (1997) “后现代思潮与中国法学和法制” (Postmodern thought and Chinese law and legal scholarship). 法学 3: 11-19.

ZHU SULI (2007) "Political parties in China's judiciary." Duke J. of Comparative \& International Law 17: 533-60.

[ZHU] SU LI 苏力 (2008) “当下中国法学教育的两项根本任务” (The two immediate fundamental tasks of legal education in China). 中国大学教学 2: 24-26.

[ZHU] SU LI (2018) The Constitution of Ancient China. Edmund Ryden, trans. Princeton, NJ: Princeton Univ. Press. 